\author{
염경훈 $^{1} \cdot$ 박상욱 $^{2} \cdot$ 양성모 ${ }^{1} \cdot$ 윤희 $^{1,2} \cdot$ 김상열 $^{1,2 \dagger}$ \\ ${ }^{1}$ 아주대학교 분자과학기술학과 \\ (ㅇ) 443-749 경기도 수원시 영통구 원천동 \\ ${ }^{2}$ (주)엘립소테크놀러지 \\ (ㅇ) 442-190 경기도 수원시 팔달구 우만동
}

개선된 투과형 타원계를 사용한 러빙된 Polyimide 배향막의 초미세 위상지연 정밀 측정

(2013년 2월 13일 받음, 2013년 3월 18일 수정본 받음, 2013년 3월 28일 게재 확정)

\begin{abstract}
시료를 회전시키는 기존의 시료회전형 타원계에서 시료를 고정시키고 편광자모듈을 회전시키는 모듈회전형 타원계로 구조를 변경하고 광원교체와 회전모듈 동기화, 배경 미세이방성 보정 등을 통해서 위상지연값 측정정밀도를 $3 \sigma<0.005 \mathrm{~nm}$ 까지 향상시 켰다. 개선된 모듈회전형 타원계를 사용하고 RVD(Retardation Vector Difference) 방법을 도입함으로써 $1.0 \mathrm{~nm}$ 정도의 잔류이방 성을 가지는 유리기층의 효과를 배제한 러빙된 Polyimide 배향막의 순수 배향효과만에 의한 초미세 광학이방성을 정밀하게 측정 하는 방법을 제시하였다. 순수 러빙으로 인한 배향막의 위상지연값은 $0.05 \mathrm{~nm}$ 에서 $0.15 \mathrm{~nm}$ 정도의 크기를 가짐을 확인하였다.
\end{abstract}

\section{Precise Measurement of Ultra Small Retardation of Rubbed Polyimide Alignment Layer Using an Improved Transmission Ellipsometer}

\author{
Kyoung Hun Lyum ${ }^{1}$, Sang Uk Park ${ }^{2}$, Seong Mo Yang ${ }^{1}$, Hee Kyu Yoon ${ }^{1,2}$, and Sang Youl Kim ${ }^{1,2 \dagger}$ \\ ${ }^{1}$ Department of Molecular Science and Technology, Ajou University, Suwon 443-749, Korea \\ ${ }^{2}$ Ellipso Technology Co., Ltd., Suwon 442-190, Korea
}

(Received February 13, 2013; Revised manuscript March 18, 2013; Accepted March 28, 2013)

\begin{abstract}
The precision of retardation measurement has been improved upto $3 \sigma<0.005 \mathrm{~nm}$ after improvements are made to the conventional transmission ellipsometer. Improvements are made such that, i) the polarizer module instead of the sample stage is rotated, ii) the light source is replaced, iii) the starting points of two rotating modules are accurately synchronized, and iv) the fine background retardation is compensated. Together with the newly introduced RVD (Retardation Vector Difference) method, the improved instrument is successfully applied to characterize the ultra small optical birefringence of the rubbed polyimide alignment layer, after the residual retardation due to glass substrate whose magnitude is about $1.0 \mathrm{~nm}$ is properly subtracted. It is verified that the net retardation of the alignment layer ranges from $0.05 \mathrm{~nm}$ to $0.15 \mathrm{~nm}$.
\end{abstract}

Keywords: Ellipsometry, Retardation, Rubbed polyimide, Alignment layer, Anisotropy

OCIS codes: (240.2130) Ellipsometry and polarimetry; (120.4630) Optical inspection; (240.0310) Thin films; (120.2040) Displays

\section{I. 연구 배경}

물질의 미세한 광학이방성을 정밀하게 측정하는 방법은 산 업체 표준검사 등의 분야에서 새로운 기준을 제시하는 하나 의 중요한 도구가 되고 있다. 예를 들어 현재 $\mathrm{LCD}$ (liquid crystal display) 산업체 현장에서 사용되고 있는 대부분의 배 향막은 유리 등의 기층에 폴리이미드(polyimide, PI)막을 코
팅하고 열경화를 거친 다음 러빙 공정 등을 거쳐 만들어 지 는데 러빙 변수가 액정의 배향성에 미치는 효과는 매우 많은 관심의 대상이 되어 왔다. 이러한 배향막이나 액정의 이방성 분포를 배향막 또는 액정의 광학이방성으로부터 이해하고자 하는 노력은 광학이방성이 큰 액정의 경우에는 비교적 성공 적으로 이루어져 왔으나 ${ }^{[1-5]}$ 배향막 만을 다룰 때에는 리타데 이션(Retardation)으로 표시한 광학이방성이 0.1-0.3 nm 정도

\footnotetext{
${ }^{\dagger}$ E-mail: sykim@ajou.ac.kr

Color versions of one or more of the figures in this paper are available online.
} 
로 매우 작기 때문에 광탄성변조기(Photo-elastic modulator, $\mathrm{PEM}$ ) 등을 사용하는 통상적인 측정방법은 배향막 자체만에 의한 광학이방성 측정에서 한계를 보인다. ${ }^{[4]}$ 그럼에도 기존 의 광학이방성 측정 방법을 사용하여 굴절률 ellipsoid의 경 사각이 $6^{\circ}$ 이하일 때 배향막의 광학이방성이 광 고분자화된 액정의 경사각이나 위상지연값과 강한 상관관계를 가짐을 보고하거나 ${ }^{[5]}$ 편광변환 도파모드법(polarization-conversion guided mode technique)을 사용하여 PI 배향막의 광학이방성 을 측정하여 이 배향막에서 러빙에 의해 광학이방성을 가지 게 되는 표면층의 평균 러빙깊이가 $7 \mathrm{~nm}$ 이고 두 개 이상의 층으로 분석되어야 함을 보고하기도 하였지만 ${ }^{[6]}$ 배향막과 같 이 광학이방성이 매우 작은 시료의 이방성 분포는 아직 알려 진 바가 없다. 한편 최근 $\mathrm{LCD}$ 산업체에서는 초고화질 $\mathrm{LCD}$ 패널의 제작공정을 상대적으로 단순하게 하기 위해서 자외 선 등을 사용한 광 배향법이 도입되고 있다. ${ }^{[7-9]}$ 광 배향막의 형성과 배향의 정도를 제어하는 것는 수율향상을 통한 경쟁 력의 제고와 밀접한 관계를 맺고 있으나 기존의 광학이방성 측정법의 정밀도는 러빙 배향 또는 광 배향에 의한 배향막 표면의 초미세 광학이방성을 평가하기에는 미흡하기 때문에 광 배향막의 미세이방성을 정밀하게 측정할 수 있는 새로운 방법이 요구되고 있다. ${ }^{[10-12]}$

아주 작은 광학이방성을 측정하는 방법으로 최근에는 Self Assembled Monolayer(SAM)의 극미소 광학이방성 $(0.003 \mathrm{~nm})$ 을 실시간으로 정밀하게 측정하는 방법이 개발되기도 하였 으나 ${ }^{[13]}$ 장비가 매우 복잡하고 사용할 수 있는 시료의 크기 가 제한되어 있으며 고가이므로 실용적이지 못하다. 본 연구 에서는 기존의 시료회전형 PCSA(polarizer-compensator-sample-analyzer) 타원계의 측정 방식과 구조 등을 대폭 변경하여 광학이방성 의 측정 정밀도와 사용자의 편의성를 대폭 향상시킴으로써 다양한 배향조건과 다양한 시료크기에 따른 배향막의 미세 이방성을 액정을 도포하기 이전 단계에서 정밀하게 측정하 고 분석할 수 있도록 하였다. 또한 유리기층의 잔류 광학이 방성을 효과적으로 측정하고 보정함으로써 이전에는 볼 수 없었던 배향막 만에 의한 초미세 알짜 위상지연의 크기를 정 밀하게 결정하였다.

\section{II. 개선된 모듈회전식 투과형 PCSA 타원계}

일반적으로 사용되는 투과형 PCSA 타원계를 사용하면 시 료와 편광자를 고정시키고도 시료의 광학이방성을 측정할 수 있지만 미세한 광학이방성을 정밀하게 측정하기 위해서 기존의 타원법에서는 그림 1(a)에서와 같이 시료를 회전시키 는 방식을 채택한다. ${ }^{[14]}$ 이같이 시료를 회전시키면서 얻는 많 은 양의 타원상수들을 시료의 방위각의 함수로 하여 종합하 여 분석하기 때문에 측정 정밀도는 향상되지만 시료를 회전 시키는 이러한 방법은 시료의 크기에 제약을 받을 뿐더러 시 료가 회전할 때 발생하는 광경로의 미세한 흔들림으로 인해 이방성의 정밀도를 한단계 더 향상시키는데 한계를 보인다. 현재 사용되고 있는 이 시료회전형 PCSA 타원계는 리타데
이션으로 표시되는 광학이방성 측정 정밀도가 $3 \sigma \approx 0.02 \mathrm{~nm}$ 인데 $0 \sim 1.0 \mathrm{~nm}$ 정도의 상대적으로 큰 잔류이방성을 가지고 있는 유리기층위에 $0.05 \sim 0.20 \mathrm{~nm}$ 정도의 위상지연값을 가지 는 배향막의 광학이방성에 대한 심도있는 연구를 수행하기 에는 극히 미흡하다. 본 연구에서는 시료의 크기에 따른 제 약을 극복하고 동시에 측정 정밀도를 한 단계 향상시키기 위 해 시료회전형 PCSA 장비를 모듈회전형 PCSA 타원계로 구 조를 변경하고 다음과 같이 측정정밀도를 향상시켰다.

먼저 그림 1(b) 에서와 같이 시료를 고정하고 편광자 모듈 을 회전시키는 방식으로 타원계를 개조하여 시료의 크기에 제약을 받지 않도록 하였다. 이 방식에서는 시료가 정지해 있으므로 시료의 회전에 따라 광경로가 미세하게 흔들리는 데에서 비롯한 위상지연 측정의 불안정성은 존재하지 않게 된다. 하지만 편광자 모듈이 회전하는 데에 따라 광경로가 미세하게 흔들릴 수 있고 이로 인한 위상지연 측정의 불안정 성이 존재하게 되는데 이 편광자 모듈의 회전에 따르는 위상 지연 측정오차를 소거하는 방법은 다음 절에서 다룬다.

광학이방성의 정도를 나타내는 위상지연값은 정상굴절률 $\left(n_{o}\right)$ 과 이상굴절률 $\left(n_{e}\right)$ 의 차이에 이방성물질의 두께 $\mathrm{d}$ 를 곱 한 값으로 정의되는데 타원상수 $\Delta$ 와 측정하는 빛의 파장 $\lambda$ (=550 nm)으로 식 (1)과 같이 쓸 수 있다. ${ }^{[14]}$

$$
\operatorname{Ret}_{0}=\left|n_{e}-n_{o}\right| d=\frac{\lambda}{2 \pi} \Delta
$$

\section{1. 편광자의 방위각 영점 보정}

기존의 시료회전형 PCSA 타원계에서 모듈회전형 방식으 로 구조를 바꿈에 따라 회전하는 검광자의 방위각 영점을 동 적으로 다음과 같이 보정하였다. 검광자의 방위각 영점은 편 광자의 투과축 영점을 기준으로 하는데 시료회전형 PCSA 타원계에서는 편광자가 고정되어 있으므로 회전하는 검광자 의 영점은 상수로써 보정과정을 통해 결정된 값을 사용한다. 그러나 편광자가 회전하게 되면 검광자의 방위각 영점도 편 광자의 회전각도에 따라 달라져야 한다. 회전하는 편광자의 방위각에 따라 검광자의 영점을 동적으로 보정하지 않으면 실제로는 존재하지 않는 타원편광성분이나 원편광성분이 반 영되어 가상적인 위상지연이 측정값에 더해진다. 동적인 영 점보정은 회전하는 편광자의 각도만큼 회전하는 검광자의 방위각 영점을 이동시켜 줌으로써 이루어 진다. 즉 회전검광 자 방식의 타원계에서 푸리에계수를 구하는 표현인 기존의 식 (2)를 식 (3)과 같이 바꿈으로써 검광자 영점을 동적으로 보정하였다.

$$
\begin{aligned}
& \alpha=\frac{1}{I_{j}} \sum_{j=1}^{N} I_{j} \cos 2 A_{j}, \beta=\frac{1}{I_{t}} \sum_{j=1}^{N} I_{j} \sin 2 A_{j} \\
& \alpha=\frac{1}{I_{t}} \sum_{j=1}^{N} I_{j} \cos \left(2 A_{j}+2 P\right), \quad \beta=\frac{1}{I_{t}} \sum_{j=1}^{N} I_{j} \sin \left(2 A_{j}+2 P\right)
\end{aligned}
$$

단

$$
I_{t}=\frac{1}{2} \sum_{j=1}^{N} I_{j}
$$




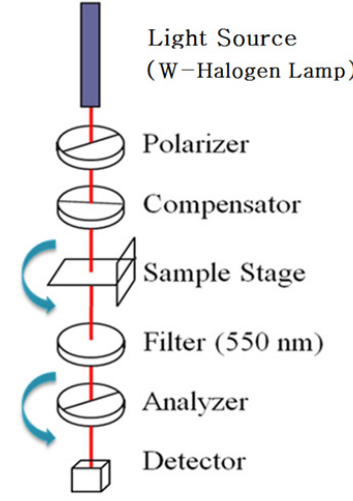

(a)

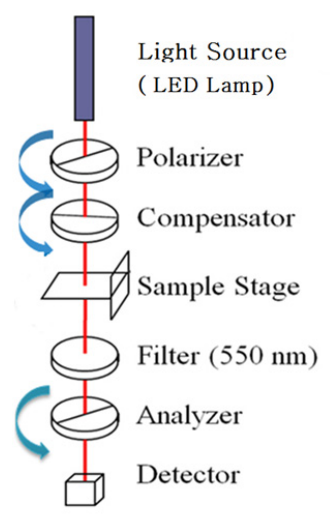

(b)
FIG. 1. Schematic diagrams of (a) the conventional PCSA type transmission ellipsometer where sample is rotated and (b) the improved PCSA type transmission ellipsometer where the polarizer module is rotated.

이다. 여기서 $A_{j}$ 와 $I_{j}$ 는 각각 $\mathrm{j}$-번째 위치에서의 검광자의 방 위각과 빛의 세기이며 $\mathrm{P}$ 는 편광자의 방위각이다.

\section{2. 회전하는 두 모듈 간의 방위각 영점 동기화}

식 (3)과 같이 편광자의 방위각을 보정해 줄 때 편광자와 검광자의 방위각 영점 동기화가 정확하게 이루어지도록 각 별한 주의를 기울였다. 모듈회전형 PCSA 타원계에서는 측 정이 시작되면 시료의 상단에 위치한 편광자 모듈이 스테핑 모터에 의해서 회전을 시작하며 하단에 위치하고 연속적으 로 회전하는 검광자 모듈의 방위각의 함수로 빛의 세기를 측 정한다. 편광자 모듈이 한 바퀴 회전하는데 걸리는 시간은 대략 18 초이며 이 동안 검광자는 대략 210 회 내외 회전한 다. 회전하는 두 모듈간의 각도 영점 설정오차는 위상지연의 측정오차로 전파되며 초미세 광학이방성을 측정할 때에는 작은 영점 설정오차도 무시하지 못하는 크기의 위상지연 측 정오차로 전파되므로 이 두 모듈의 방위각 영점을 정확하게 동기화하고 매 측정 순간 검광자의 각도를 정확하게 입력해 주어야 한다. 검광자는 그림 2에서와 같이 중공축 엔코더와 동축상에 장착되고 이들은 타이밍 풀리와 타이밍 벨트를 통 하여 소형 DC 모터에 의해 일정한 속도로 회전하게 된다. 검광자의 방위각은 이 검광자와 동축상에 장착되어 있는 엔 코더에서 나오는 TTL 펄스의 순번에 비례하게 대응시킨다. 엔코더는 회전의 영점 정보와 회전각도 정보를 보내주는 일 종의 센서로서 한 바퀴 회전할 때 두 가지 종류의 TTL 펄스 를 내보낸다. 하나는 매 회전마다 단 한번 내보내는 $\mathrm{Tz}$ 펄스 이며 다른 하나는 한 회전당 $\mathrm{N}$ 회 내보내는 $\mathrm{A}$ 펄스이다. 본 연구에서 사용된 엔코더의 A 펄스 수는 $\mathrm{N}(=2048)$ 이다. 측 정이 시작되면 $\mathrm{Tz}$ 펄스 신호가 입력된 다음부터 $\mathrm{A}$ 펄스 신 호에 전자적으로 동기화되어 빛의 세기를 $\mathrm{A} / \mathrm{D}$ 수치변환할 수 있도록 전자회로가 설계되어 있고 식 (4)와 같이 A 펄스 가 입력되는 순번에 비례하여 검광자의 방위각을 할당한다.

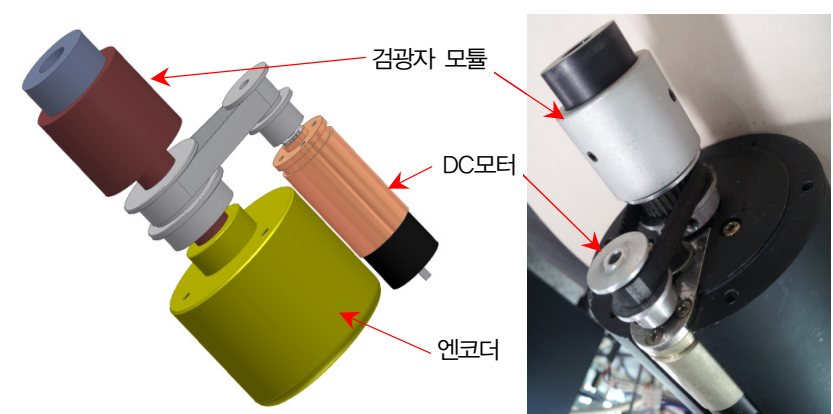

FIG. 2. The analyzer is mounted concentrically on the hollow axis of an encoder, which is driven at constant angular velocity by a DC motor.

$A_{j}=j \times \frac{360^{\circ}}{N}, j(=1,2, . ., \mathrm{N})$ 는 엔코더 $\mathrm{A}$ 펄스의 순번

한편 편광자모듈의 방위각 영점과 검광자의 방위각 영점을 동기화 하는 작업은 보다 정교하게 다루어야 한다. TTL 전 기신호 형태로 주어지는 명령에 따라 스테핑 모터의 드라이 버가 정지상태에 있던 편광자모듈을 회전하게 한 후 검광자 가 장착된 중공축 엔코더의 $\mathrm{Tz}$ 펄스 신호 및 $\mathrm{A}$ 펄스 신호가 도착하여 $\mathrm{A} / \mathrm{D}$ 변환이 시작되는 시점은 $0 \mathrm{~ms}$ 부터 $85 \mathrm{~ms}$ 사 이로 불규칙하게 시간지연되는데 이렇게 지연되는 시간을 정확하게 반영하지 않을 경우 영점설정오차는 최대 1.7 도 까지가 되어 미세한 이방성을 측정할 때 큰 오차요인으로 작 용할 수 있다.

이 영점설정오차를 없애기 위해 다음과 같이 하였다. 스테 핑 모터 구동을 시작하라는 신호가 발생되는 시각을 기준으 로 하여 회전하는 엔코더로부터 방출되는 $\mathrm{Tz}$ 신호 및 $\mathrm{A}$ 신 호의 방출시각을 측정한 다음 이 방출시각으로부터 편광자 의 영점위치를 계산하였다. 즉 편광자모듈을 한 바퀴 회전시 키는데 필요한 스테핑펄스 수를 $N_{t}$, 스테핑모터의 드라이버 가 방출하는 초당 펄스 수를 $N_{s}$, 편광자 모듈이 회전을 시작 한 후 엔코더에서 $\mathrm{Tz}$ 펄스가 방출되는 시각을 $t_{T z}$ 라 두면 이 $\mathrm{Tz}$ 펄스가 방출될 때 편광자의 방위각은 다음 식 (5)와 같다.

$$
P=360^{\circ}\left(\frac{N_{s} \times t_{T z}}{N_{t}}\right)
$$

한편 Win7에서 제공되는 시간측정모듈의 정밀도는 $16 \mathrm{~ms}$ 정도로 본 연구에서 요구하는 시각 측정 정밀도에 크게 못 미친다. 본 연구에서는 측정 정밀도가 $1 \mathrm{~ns}$ 인 Query Performance Frequency 함수와 QueryPerformanceCounter 함수를 사용하 여 시각을 측정하였다.

\section{3. 광원의 교체 및 잡음 수준 저감}

시스템 변경 및 이에 따른 수식 보정과 더불어 측정 정밀 도를 더욱 향상시키기 위하여 광원과 전원 그리고 전자회로 등에서 기인하는 데이터 불안요소를 감소시켰다. 특히 광원 

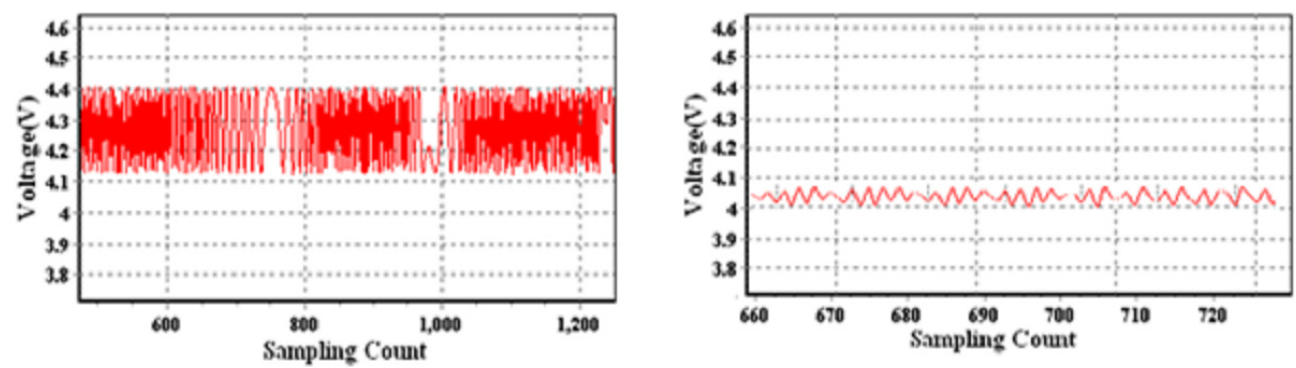

FIG. 3. The noise level of a commercial LED (left) is drastically reduced after a stability enhanced electric circuit is introduced (right).
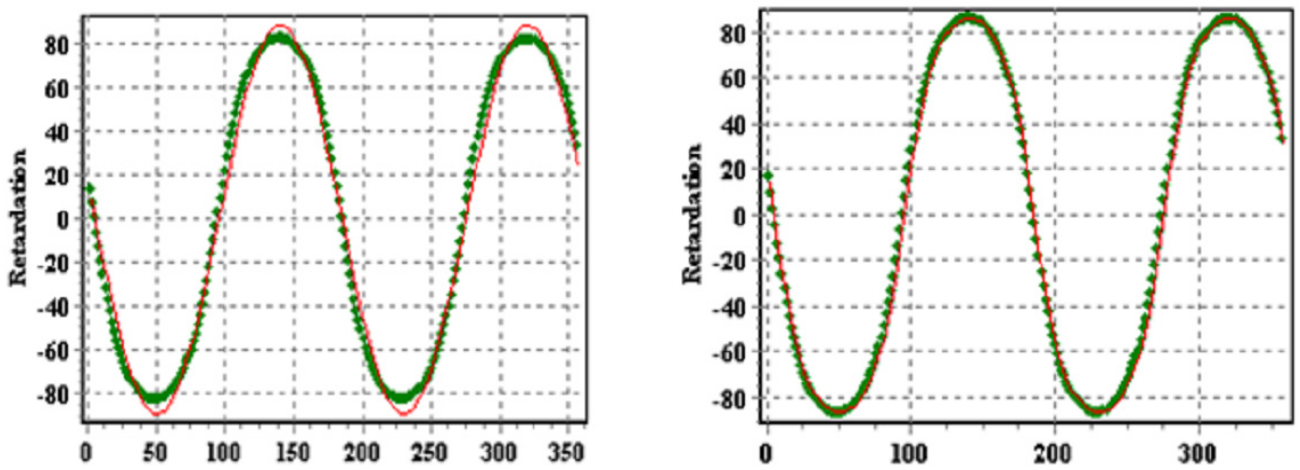

FIG. 4. The measured retardation of the phase plate(symbols) and the best fit(lines) to the measured ones whose retardation is $85.98 \mathrm{~nm}$. When the approximate expression of Eq. (6) is used the fit is not satisfactory (left) but when the exact expression of Eq. (7) is used the fit is quite excellent (right).

에서 발생하는 노이즈는 측정 결과에 직접적인 영향을 주는 데, 기존의 $100 \mathrm{~W}$ 할로겐램프는 소모전력에 비해 광량이 작 아 $\mathrm{S} / \mathrm{N}$ 비가 낮으며 측정에 사용되지 않는 파장의 빛이 국지 적으로 시료의 온도를 상승시켜 측정값의 완만한 변화를 일 으키므로 광원을 LED 램프로 대체하였다. 하지만 일반적인 조명용 LED 램프는 그림 3 의 좌측그림과 같이 잡음 수준 (noise level)이 0.3 Volt 정도로 높게 나타나므로 LED의 전 원에 안정화 회로를 추가하고 전기적 노이즈 필터를 설치하 여 그림 3 의 우측그림에서와 같이 이 잡음 수준을 $0.05 \mathrm{Volt}$ 이하로 감소시켰다.

\section{4. 미소 이방성 영역에서 큰 이방성 영역까지 측정대역 확장}

식 (1)의 위상지연값 $\operatorname{Ret}_{0}$ 은 겉보기 위상지연값인 $\operatorname{Ret}_{a p p}$ 을 회전하는 시료의 방위각 $\theta_{s}$ 의 함수로 아래식 (6)에 최적 맞춤하여 구한 것인데 이 식 (6)은 시료의 위상지연의 크기 가 매우 작을 때에만 적용되는 근사식이다. ${ }^{[15]}$ 여기서 $\theta_{R}$ 은 시료의 광축의 방위각을 나타낸다.

$$
\operatorname{Ret}_{a p p}\left(\theta_{s}\right)=\operatorname{Ret}_{0} \sin \left(2 \theta_{s-} 2 \theta_{R}\right)
$$

시료의 위상지연이 수십 $\mathrm{nm}$ 이상으로 큰 시료의 겉보기 위상지연값은 식 (6)으로 근사되지 않는다. 본 연구에서는 아래 식 (7)과 같이 겉보기 위상지연이 클 경우에도 편광자
방위각 의존성을 정확하게 반영하는 표현을 사용하여 광학 이방성의 크기와 무관하게 광축과 위상지연값을 정확하게 결정할 수 있도록 하였다.

$$
\sin \Delta_{a p p}(P)=\frac{\sin \Delta \times \sin \left(2 P-2 \theta_{R}\right)}{\sqrt{1-\sin ^{2} \Delta \times \sin ^{2}\left(2 P-2 \theta_{R}\right)}}
$$

식 (7)에서 $\Delta_{a p p}$ 과 $\Delta$ 는 각각 겉보기 타원상수와 시료의 타원상수이다. 참고로 시료가 회전하며(편광자는 고정) 광학 이방성이 매우 작을 경우에는 식 (7)에서 편광자의 방위각인 $\mathrm{P}$ 를 시료의 방위각 $\theta_{s}$ 로 치환하고 $\sin \Delta_{a p p} \approx \Delta_{a p p}=\frac{2 \pi}{\lambda} \operatorname{Ret}_{a p p}$, $\sin \Delta \approx \Delta=\frac{2 \pi}{\lambda} \operatorname{Ret}_{0}$ 그리고 $\sin ^{2} \Delta \approx 0$ 으로 근사하면 식 (7) 은 식 (6)과 같아진다. 그림 4의 두 그림들은 각각 식 (6) 또 는 식 (7)으로 최적맞춤한 그래프들인데 이방성이 큰 시료의 경우 식 (6)으로는 정확히 맞춤되지 않으나 식 (7)을 적용하 면 정확하게 맞춤되는 것을 확인할 수 있다.

\section{5. 편광자모듈의 회전에 따르는 광경로 흔들림 보정} 앞에서 설명한 바와 같이 편광자모듈을 회전시키게 되면 미세하나마 광경로가 흔들리게 되고 이로 인한 위상지연 측 정값이 불안정해 지는데 이 불안정성을 다음과 같이 제거하 였다. 먼저 시료를 두지 않고 편광자모듈을 회전시키며 겉보 
기 위상지연을 측정하면 이 값은 공기만에 의한 위상지연이 므로 이상적인 광학계로 구성되어 있을 경우 0 이어야 한다. 실제로 이 겉보기 위상지연값을 편광자모듈의 방위각의 함 수로 그리면 그림 5 와 같이 크기가 $0.459 \mathrm{~nm}$ 정도이며 주기 가 180 도인 진동형태를 보여주는데 이를 배경 위상지연값

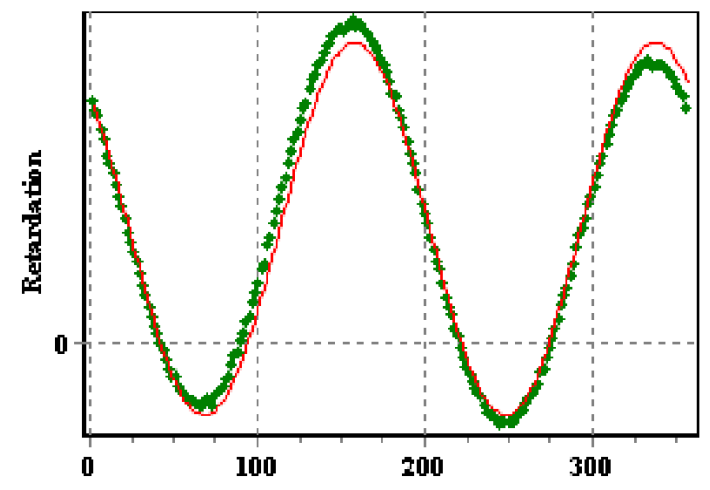

FIG. 5. The measured retardation (symbols) of a null sample(air) shows the effect of small misalignment of the proposed transmission ellipsometer, where the polarizer module is rotated. The best fit line is slightly off from the measured one, which is saved as the background retardation of the system and subtracted on each successive measurement.

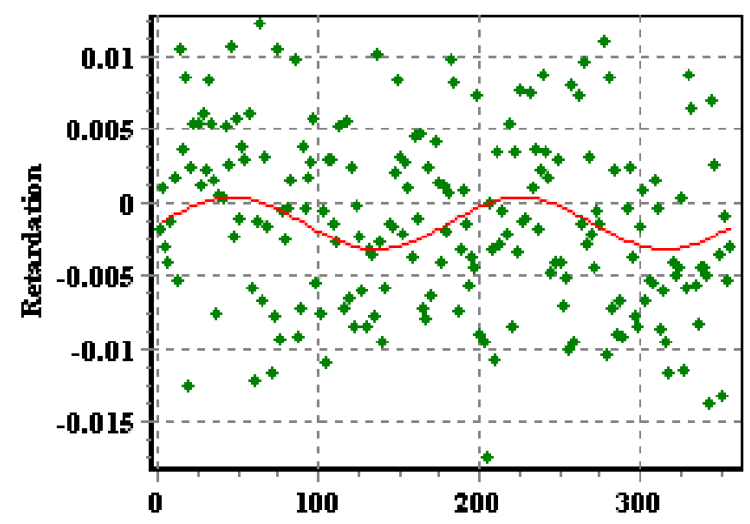

FIG. 6. The measured retardation(symbols) of a null sample(air) is flat and random around zero when the background retardation is subtracted. The best fit result(line) shows that the retardation of the null sample(air) is less than $0.002 \mathrm{~nm}$.
으로 저장한 다음 실제 시료의 위상지연 측정값에서 빼준다. 그림 6은 이 배경 위상지연값을 빼준 공기의 위상지연값으 로 그림 5의 모양이 상쇄되고 위상지연값도 $0.002 \mathrm{~nm}$ 이하 로 측정되어 미세한 광학이방성을 정밀하게 측정할 수 있음 을 확인할 수 있다. 그림 5와 그림 6에서 점으로 표시된 것 은 측정값이며 실선으로 표시된 것은 식 (7)에 따라 최적맞 춤한 그래프이다.

\section{6. 장비 개선 요약 및 결과}

시료회전 방식에서 모듈회전 방식으로 타원계의 구조를 바 꿈으로써 측정가능한 시료크기를 $50 \times 50 \mathrm{~mm}^{2}$ 에서 10 세대의 초대형 유리시료 또는 이보다 더 큰 유리시료의 크기로 확대 시켰다. 회전검광자와 회전편광자의 영점을 정밀하게 동기화 함으로써 각도설정오차에서 기인하는 측정 정밀도 감소요인 을 제거하였다. 또한 편광자모듈의 회전과 연계된 광경로의 흔들림이 유발하는 배경 위상지연값을 빼 줌으로써 초미세 광학이방성을 안정하게 측정할 수 있도록 하였다. 기존에 사 용하였던 할로겐램프를 LED로 바꾸고 전원 안정화 회로 및 잡음제거 필터를 사용하여 잡음수준을 크게 줄였으며 위상 지연이 매우 작을 경우에만 적용되는 근사식 대신에 위상지 연이 큰 시료에도 적용할 수 있도록 겉보기 위상지연값을 표 현하는 기존의 수식을 일반화하였다. 이상과 같이 하여 모듈 회전 방식으로 개선된 타원계를 시료회전 방식의 기존의 타 원계와 비교한 결과는 표 1 에 정리하였다. 이 표에서 확인할 수 있는 것처럼 개선된 모듈회전형 타원계의 대표적인 장점 들은 측정할 수 있는 시료의 크기가 10 세대 이상의 대형 유 리로 확대되었고 위상지연 측정정밀도가 $3 \sigma \leq 0.005 \mathrm{~nm}$ 로 기존의 시료회전형에 비해 4 배 정도 향상된 점이다.

\section{III. 러빙된 Polyimide 배향막의 광학이방성 측정}

\subsection{RVD(Retardation Vector Difference) 방법의 도입} 배향막의 미세 광학이방성을 측정할 수 있을 정도로 투과 형 타원계의 측정 정밀도가 향상되었으므로 배향막 만에 의 한 순수 광학이방성을 측정하고자 하였다. 산업체 현장에서 사용하고 있는 대형 유리시료는 실험실에서 사용하는 소형 유리시료와는 달리 유리내부에 잔류응력(Residual stress)이 존재하며 이 잔류응력으로 인한 광학이방성이 존재한다. 따

TABLE 1. Comparison of a few specifications of the conventional transmission ellipsometer with those of the improved one

\begin{tabular}{|c|c|c|}
\hline $\begin{array}{ll} & \text { Type }\end{array}$ & Rotating Sample Type & Rotating Module Type \\
\hline 1. Measurement Speed & $<25 \mathrm{sec} / \mathrm{pt}$ & $<18 \mathrm{sec} / \mathrm{pt}$ \\
\hline 2. Retardation Repeatability & $3 \sigma \simeq 0.02 \mathrm{~nm}$ & $3 \sigma \leq 0.005 \mathrm{~nm}$ \\
\hline 3. Sample Size & Small $\left(50 \times 50 \mathrm{~mm}^{2}\right)$ & Large (7-10 $\mathrm{G}$ glass or larger) \\
\hline 4. Beam Spot Size & $10 \mathrm{~mm}$ & $10 \mathrm{~mm}$ \\
\hline 5. Auto Mapping & No & Yes \\
\hline 6. Wavelength & $550 \mathrm{~nm}$ & $550 \mathrm{~nm}$ \\
\hline 7. Large Retardation & No & Yes \\
\hline
\end{tabular}


TABLE 2. Procedure of sample preparation for measurement of the net optical birefringence of rubbed PI layers

\begin{tabular}{c|c|c|c|c}
\hline \hline Glass No. & Heating Temp. $\left({ }^{\circ} \mathrm{C}\right)$ & Quenching & PI Coating & Rubbing \\
\hline G1 & 400 & $\bigcirc$ & $\bigcirc$ & $\bigcirc$ \\
\hline G2 & 450 & $\bigcirc$ & $\bigcirc$ & $\bigcirc$ \\
\hline G3 & $\times$ & $\times$ & $\bigcirc$ & $\bigcirc$ \\
\hline
\end{tabular}

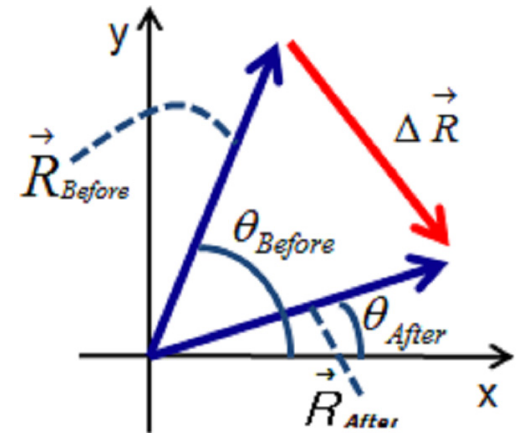

FIG. 7. Retardation difference vector $\Delta \vec{R}$ is defined as the difference between $\vec{R}_{\text {after }}$ and $\vec{R}_{\text {before }}$.

라서 러빙 후의 전체 광학이방성에서 이 잔류응력에 의한 광 학이방성을 적절하게 빼 주어야 순수 러빙만에 의한 광학이 방성을 구할 수 있다. 이를 위해 다음과 같이 RVD (Retardation vector difference) 방법을 도입하였다. RVD 방법은 그림 7과 같이 배향막에 의한 이방성을 포함한 전체 리타데이션 벡터 $\vec{R}_{\text {after }}$ 에서 기층에 의한 리타데이션 벡터인 $\vec{R}_{\text {before }}$ 를 빼주는 방식이다. 여기에서 사용되는 리타데이션 벡터의 크기는 식 (1)의 위상지연값과 같으며 방향은 광축의 방향과 같다. 배 향막 만에 의한 리타데이션 벡터 $\Delta \vec{R}$ 은 식 (8)과 같이 정의 한다.

$$
\Delta \vec{R}=\vec{R}_{\text {after }}-\vec{R}_{\text {before }}
$$

\section{2. 시료준비, 측정 및 검토}

$\mathrm{LCD}$ 배향막 만에 의한 이방성을 측정하기 위해 4 인치 크 기의 ITO 유리 기판을 세 장 사용하였는데 이 정도 크기의 유리 기판에서는 잔류응력이 매우 약하고 이로 인한 이방성
도 매우 작다. 이 유리 기판에 인공적으로 잔류응력을 남기 기 위해 유리 기판을 가열하고 급속냉각한 다음 PI 코팅을 하고 러빙하는 과정을 표 2 와 같이 진행하였다. 이 중에서 $\mathrm{PI}$ 코팅공정과 러빙공정은 경희대학교의 RIC CAMID 연구 센터에서 진행하였다.

\subsection{1. 열처리 공정}

첫 번째 공정은 실험에 사용한 유리 기판의 크기가 $100 \times 100$ $\mathrm{mm}^{2}$ 으로 산업체 현장에서 사용되는 7-10 세대 대형 유리기 판과 다르게 내부에 잔류응력이 상대적으로 적게 존재하므 로 인위적으로 잔류응력을 만들어 주기 위하여 ITO 유리 기 판을 가열한 뒤 바로 찬물에 담가 급속냉각(Quenching)하는 공정이다.

$\mathrm{G} 1$ 시료와 $\mathrm{G} 2$ 시료는 각각 400 도와 450 도로 가열하였고 $\mathrm{G} 3$ 시료는 대조군으로 사용하기 위하여 열처리 공정을 진행 하지 않았다. 열처리에 의한 이들의 위상지연 변화는 그림 8 과 같다. 위상지연은 $100 \times 100 \mathrm{~mm}^{2}$ 의 면적을 등간격으로 16 등분하여 각 등분위치에서 측정하였다. 열처리를 하였던 $\mathrm{G1}$ 시료와 G2 시료의 경우 열처리를 하지 않은 G3 시료에 비해 전체적으로 위상지연값이 대폭 상승한 형태를 보였는데 가 장자리쪽 위상지연이 더 크게 관찰되었다. 이는 유리 기판을 가열할 때 사용한 스테인레스판의 열 분포가 바깥쪽 부분에 서 20-30 도 정도 더 높았고 찬물에 담글 때 물에 먼저 들어 간 부분이 더 많은 잔류응력을 가진 것으로 해석되며 이는 그림 8의 위상지연값의 공간 분포를 통해서 확인할 수 있다. 잔류응력을 주지 않은 $\mathrm{G} 3$ 시료는 위상지연이 거의 0 에 가까 웠다.

\subsubsection{PI 코팅공정}

$\mathrm{G} 1$ 시료, G2 시료, 그리고 G3 시료에 PI를 코팅한 뒤 위상

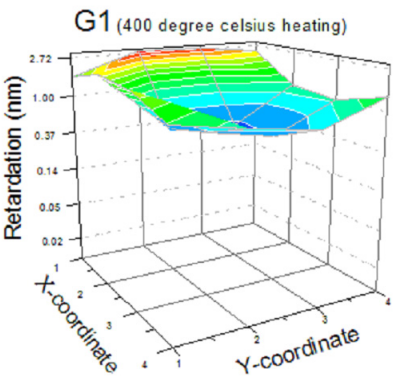

(a)

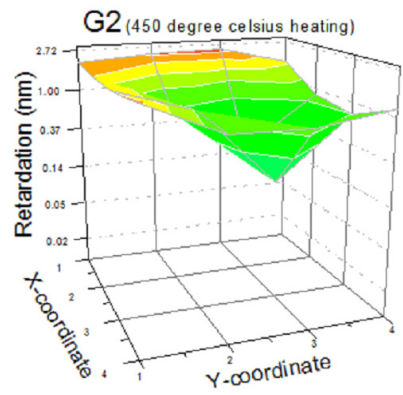

(b)

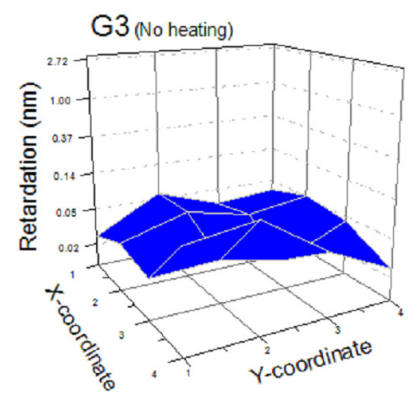

(c)

FIG. 8. Measured retardation of ITO glasses after heat treatment at (a) $400{ }^{\circ} \mathrm{C}$, (b) $450{ }^{\circ} \mathrm{C}$, and (c) that with no heat treatment. 
지연의 변화를 측정하였다. 그 결과는 그림 9 와 같은데 $\mathrm{G1}$ 시료와 $\mathrm{G} 2$ 시료의 경우 위상지연이 약간 감소하였고 $\mathrm{G} 3$ 시 료의 경우 위상지연이 소폭 증가하였다. 동일한 PI 코팅공정 을 거쳤음에도 불구하고 위상지연의 변화가 다르게 나타난 이유는 PI 코팅공정이 폴리아믹산(polyamic acid)을 균일하 게 도포한 후 스핀코터(Spin coater)로 약 180 도에서 한시간 반 정도 열경화 과정을 거치는 공정이기 때문으로 판단된다. $\mathrm{G} 1$ 시료와 $\mathrm{G} 2$ 시료는 열경화 과정에서 기존의 열처리 공정 에 의한 잔류응력이 다소 해소되어 위상지연이 감소하는 반 면 G3 시료는 PI 코팅 및 열경화 과정의 영향으로 위상지연 이 소폭 증가하는 것으로 해석된다.

\subsection{3. 러빙 공정}

마지막으로 코팅된 PI 막을 러빙배향한 다음 배향된 PI 막 의 위상지연을 측정하였다. 그 결과 그림 10 과 같이 $\mathrm{G} 1$ 시 료, G2 시료, 그리고 $\mathrm{G} 3$ 시료 공통적으로 위상지연값이 소 폭 증가하였다. 하지만 동일한 러빙배향을 행하였지만 기층 의 잔류응력이 존재하는 $\mathrm{G} 1$ 시료와 $\mathrm{G} 2$ 시료는 위상지연의 차이가 극히 작은데 비해 기층의 잔류응력이 무시되는 $\mathrm{G} 3$ 시료는 배향 전후의 위상지연의 차이가 비교적 크다.

이와 같은 일련의 측정 및 분석을 통해 기층의 잔류응력이 클 경우에는 배향 후의 위상지연값만으로 배향의 정도나 배 향의 여부를 파악할 수 없다는 것을 알 수 있다. 배향막 만 에 의한 위상지연을 파악하기 위해 RVD 방법에 따라 러빙
후의 전체 리타데이션 벡터에서 러빙 전의 리타데이션 벡터 를 뺀 리타데이션 벡터를 구한 다음 그 크기를 그린 결과는 그림 11 과 같다. 그림 11 에서 볼 수 있듯이 잔류응력에 의한 위상지연이 크게 존재하는 G1 시료와 G2 시료, 그리고 잔류 응력에 의한 위상지연이 매우 작은 $\mathrm{G} 3$ 시료 모두 배향막에 의한 위상지연값이 0.05-0.15 nm의 크기를 가지며 시료의 위 치에 따른 편차가 적은 평평한 형태로 나타났다. 요약하면 러빙 후의 위상지연 측정데이터 만으로는 러빙에 따르는 배 향막의 형성여부를 파악할 수 없지만 기층효과를 제거해 주 면 순수 러빙에 의한 미세한 광학이방성을 정밀하게 결정할 수 있음을 확인하였다.

\section{IV. 결론 및 검토}

기존의 시료회전형 PCSA 투과형 타원계를 모듈회전형으 로 구조를 변경하고 광원교체, 회전 모듈들의 방위각 영점보 정, 배경 위상지연값 처리, 기타 수식보정 등을 해준 결과 위 상지연 측정 정밀도가 $3 \sigma \leq 0.005 \mathrm{~nm}$ 로 대폭 향상되었다. 새로 도입된 RVD 방법에 따라 유리 기판의 잔류응력에 의 한 리타데이션 벡터를 빼 줌으로써 러빙된 PI 배향막 만에 의한 초미세 광학이방성을 결정하고 러빙에 의한 배향막의 형성여부를 판단할 수 있었다. 러빙배향에 의한 알짜 위상지 연값은 0.05-0.15 nm 정도였으며 유리 기판의 위치에 무관하 게 비슷한 크기인 것으로 파악되었다.

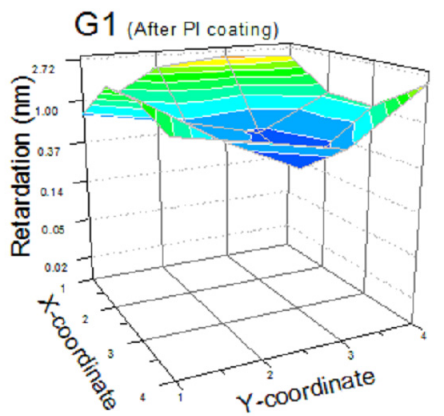

(a)

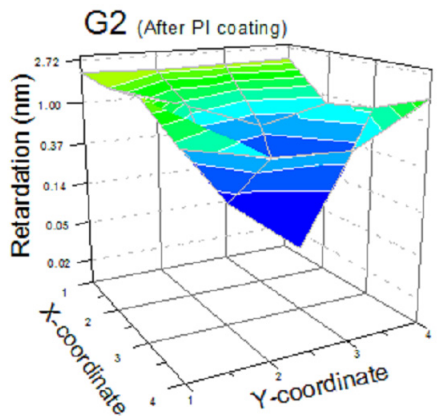

(b)

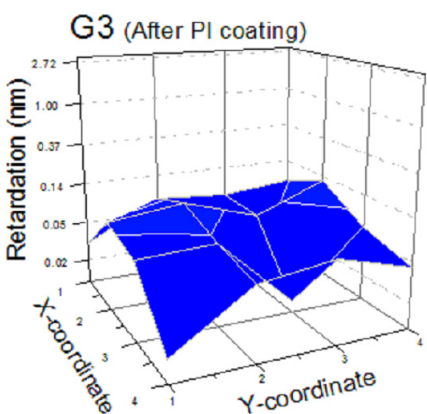

(c)

FIG. 9. Measured retardation after PI is coated on the ITO glasses which are previously heat treated at (a) $400{ }^{\circ} \mathrm{C}$, (b) $450{ }^{\circ} \mathrm{C}$, and (c) that with no heat treatment.

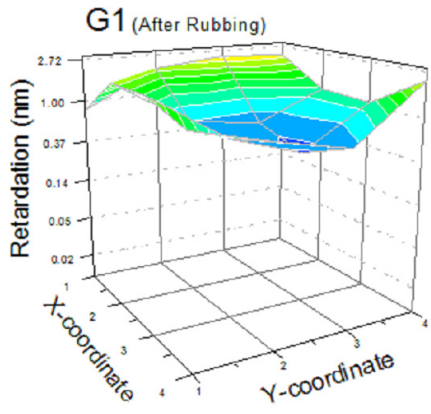

(a)

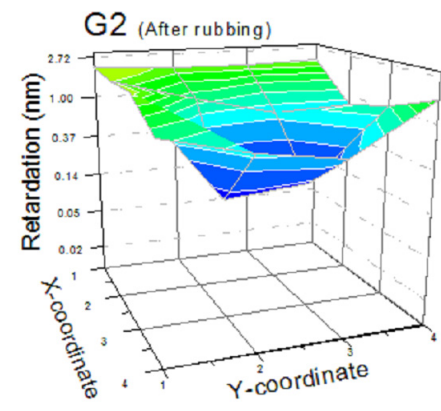

(b)

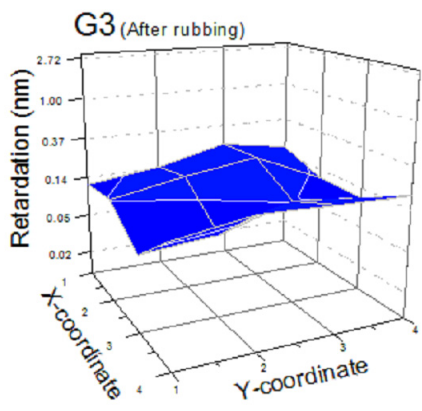

(c)

FIG 10. Measured retardation after rubbing process on the PI coated ITO glasses which are previously heat treated at (a) $400{ }^{\circ} \mathrm{C}$, (b) 450 ${ }^{\circ} \mathrm{C}$, and (c) that with no heat treatment. 


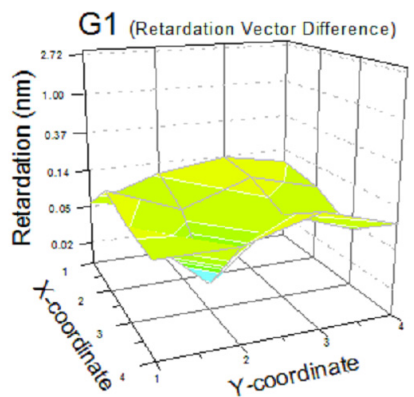

(a)

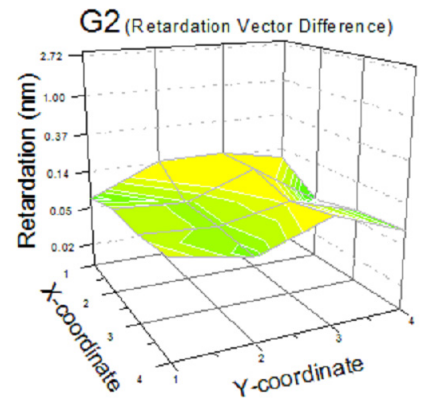

(b)

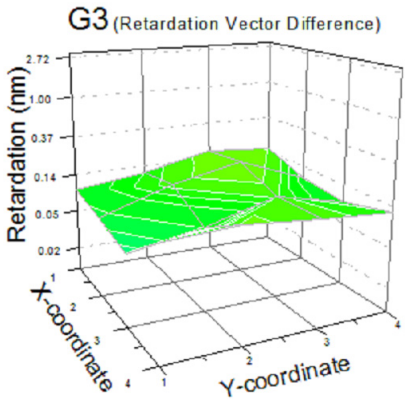

(c)

FIG. 11. The net retardations of the rubbed PI show nearly constant and approximately the same values ranging from $0.05 \mathrm{~nm}$ to $0.15 \mathrm{~nm}$ regardless of the heat treatment. Sample are previously heat treated at (a) $400{ }^{\circ} \mathrm{C}$, (b) $450{ }^{\circ} \mathrm{C}$, and (c) that with no heat treatment.

본 연구에서 제시한 장치와 방법은 다양한 시료의 이방성 을 정밀하게 측정하고 분석하는데 유용하게 사용될 수 있을 것으로 기대된다. 배향막의 경우 유리기층에 의한 효과를 제 외하면 배향공정에 의해 형성되는 표면층의 위상지연값이 러빙배향의 경우에는 $0.20-0.30 \mathrm{~nm}$ 정도가 되며 광배향의 경 우 0.08-0.20 nm 정도가 되는데 배향이 되지 않은 영역은 $0.02 \mathrm{~nm}$ 이하의 작은 값을 가진다. 따라서 본 연구에서 개발 된 방법을 사용하면 배향막 형성 직후 액정을 도포하기 이전 에 배향막의 불량여부를 확인할 수 있으므로 배향불량에 의 한 수율감소를 크게 줄일 수 있으며 최적의 배향조건을 찾거 나 새로운 배향시료를 개발하는 데에도 기여할 것으로 예상 된다. 한편 원판 유리의 잔류응력 또한 정밀하게 측정함으로 써 디스플레이 공정에서 발생하는 잔류응력에 의한 불량을 줄이고 수율을 향상시키는데 기여할 수 있을 것으로 예상된 다. 특히 시료를 고정하고 측정 모듈을 회전시키는 모듈회전 방식이기 때문에 $2850 \times 3050 \mathrm{~mm}^{2}$ 의 10 세대 유리 기판을 포 함한 모든 크기의 시료에 유연하게 대응할 수 있게 되어 in-line용 장비로의 활용성도 열려 있어서 관련 산업 분야에 유용하게 사용될 수 있을 것으로 예상된다.

한편 학문적으로는 박막 형태 시료의 고유 미세이방성 측 정은 물론이고, 유체의 미세이방성 크기 및 방향 측정, 약하 게 외력이 가해졌을 때의 단결정의 이방성 미세변화, 자기광 학 시료에 자기장을 걸었을 때의 약한 이방성 변화 등의 기 초 및 응용 분야에 본 연구에서 제시되는 장치와 방법이 광 범위하게 적용할 수 있을 것으로 기대된다.

\section{감사의 글}

본 연구는 한국연구재단에서 지원한 2011년도 일반연구자 지원사업(과제명: 초미세 광학이방성 측정장비의 개발 및 $\mathrm{LCD}$ 배향막의 이방성 분포 연구)의 연구비 지원을 받아 이 루어 졌습니다.

\section{References}

1. C. Benecke, H. Seiberle, and M. Schadt, "Determination of director distribution in liquid crystal polymer-films by means of generalized anisotropic ellipsometry," Jpn. J. Appl. Phys. 39, 525-531 (2000).

2. J. A. Ekhoff, M. J. Farrow, D. M. Walba, and K. L. Rowlen, "Molecular orientation of a model liquid crystal alignment layer," Talanta 60, 801-808 (2003).

3. J. W. Ryu, S. Y. Kim, and Y. K. Kim, "Determination of the optic axis distribution of a hybridly aligned discotic material for wide-view films," J. Korean Phys. Soc. 57, 233-239 (2010).

4. C. Yu, J. Bae, C. M. Keum, and S. D. Lee, "Optical anisotropy of aligned pentacene molecules on a rubbed polymer corresponding to the electrical anisotropy," Current Applied Physics 10, 64-67 (2010).

5. M. Yamahara, M. Nakamura, N. Koide, and T. Sasaki, "Influence of rubbing conditions of polyimide alignment layer on optical anisotropy of immobilized liquid crystal film," Liquid Crystals 34, 381-387 (2007).

6. F. Yang, G. Zoriniants, L. Ruan, and J. R. Sambles, "Optical anisotropy and liquid-crystal alignment properties of rubbed polyimide layers," Liquid Crystals 34, 1433-1441 (2007).

7. K. Ichimura, Y. Susuki, T. Seki, A. Hosoki, and K. Aoki, "Reversible change in alignment mode of nematic liquid crystals regulated photochemically by command surfaces modified with an azobenzene monolayer," Langmuir 4, 1214-1216 (1988).

8. K. Miyachi, N. Kimura, Y. Yamada, and S. Mizushima, "The UV ${ }^{2}$ A technology for large size LCD-TV panels," in Proc. The 17th International Display Workshops (Fukuoka, Japan, Dec. 2010), LCT1-1.

9. S.-H. Kang, K. Kim, J. Lee, B. Jeon, J. Yeom, and S.-R. Cho, "Method of forming alignment layer and fabrication method of liquid crystal display using the same," Patent KR-20120301983 (2012).

10. S.-Y. Kim, "The study of photo-sensitive polyimide containing methoxy cinnamate derivatives on photoalignment of liquid crystal," M.S. Thesis, Hongik University, 
Seoul (2011).

11. S. U. Park, S. Y. Kim, and K. H. Lyum, "Precise measurement of ultra small optical anisotropy and substrate effect to LCD alignment layer versus rubbing strength by using transmission ellipsometry," IMID 2011 Program, 51-3.

12. http://www.ellipsotech.com/Ellipsometer_02.html.

13. G. Fang, J. Maclennan, and N. Clark, "High extinction polarimeter for the precision measurement of the in-plane optical anisotropy of molecular monolayers," Langmuir 26,
11686-11689 (2010).

14. H. R. Kim and S. Y. Kim, "Precise measurement of optical anisotropy of rubbed polyimide on patterned glass and its nanoscale variation," Korean J. Opt. Photon. (Hankook Kwanghak Hoeji) 20, 281-287 (2009).

15. J. W. Ryu and S. Y. Kim, "Analysis of effective optic axis and equivalent retardation of composite optically anisotropic film by using transmission ellipsometry," Korean J. Opt. Photon. (Hankook Kwanghak Hoeji) 20, 288-293 (2009). 